\title{
FLOOD TRACKING CHART, AMITE RIVER BASIN, LOUISIANA
}

U.S. Geological Survey Open-File Report 96-649
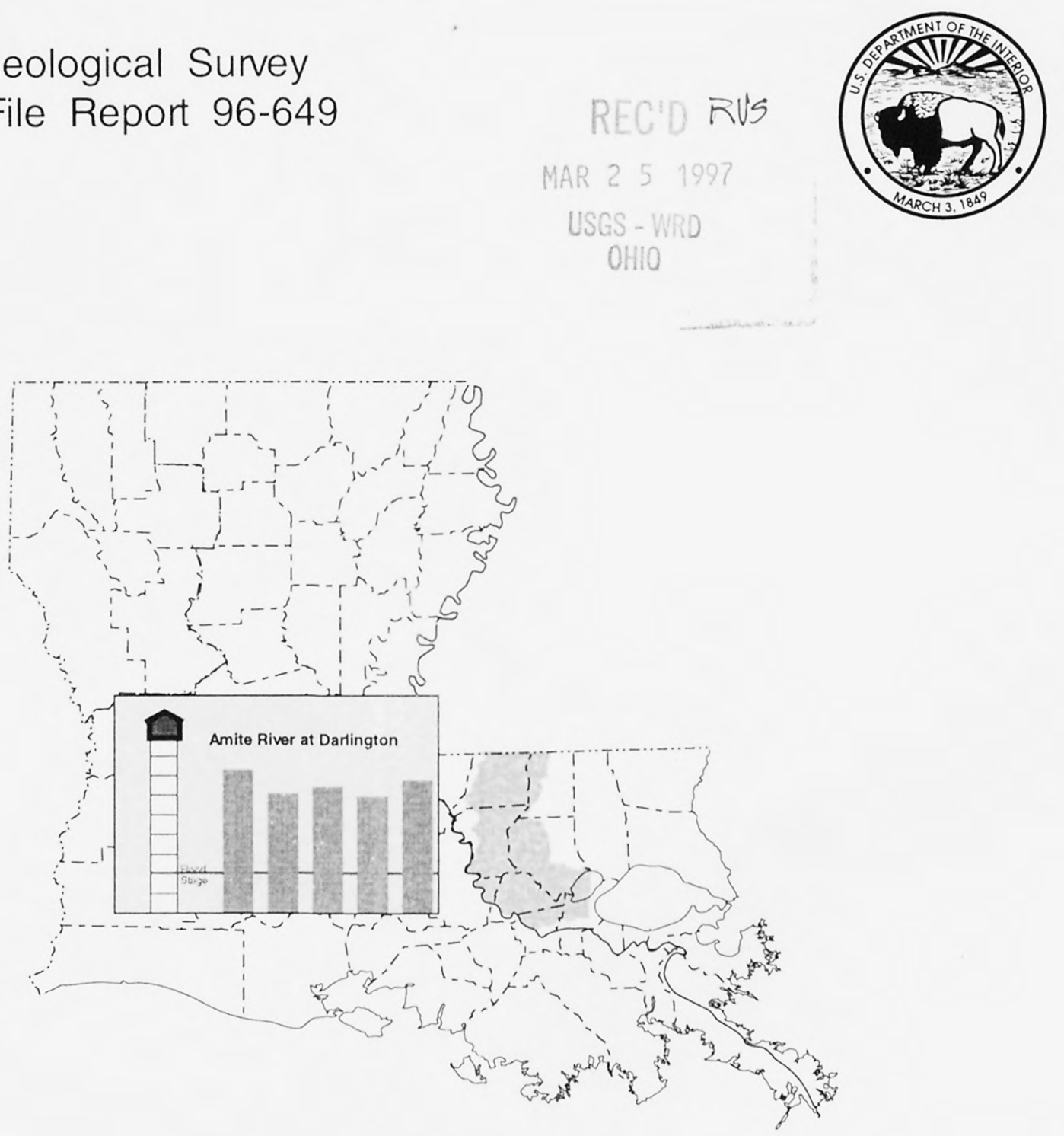

Prepared in cooperation with the AMITE RIVER BASIN DRAINAGE AND WATER CONSERVATION DISTRICT 


\section{FLOOD TRACKING CHART}

AMITE RIVER BASIN, L OUISIANA

This Amite River Basin Flood Tracking Chart can be used by local citizens and emergency response personnel to record the flood crest information along the Amite and Comite Rivers and Bayou Manchac. By comparing Bayou Manchac. By comparing
the current stage (water-surface elevation above some datum) and predicted flood crest to the

recorded peak stages of previous floods, emergency response

personnel and residents can make an informed decision concerning the threat to life and property. This chart shows a map of the basin, with the location of major real-time stream gaging stations and the historical recorded peak stages at each station. Each station has a scale on which to record the most recently reported river stage from the U.S

Geological Survey (USGS). Also for each station, the predicted flood crest information from the National Weather Service NWS) can be recorded.

During a flood, the USGS provides current river stage information to the public through news releases, and more directly through the USGS "Home Page" on the Internet and a voice

message:

The Louisiana District of the USGS displays available rea time river stage data on the World Wide Web at the following Uniform Resource Locator (URL) address: http://wwwdlabrg.er.usgs.gov/ public/dist000.htm

A voice message, which is updated by the USGS, gives the latest river stages; it can be accessed by calling the Advocate Info Line a ${ }^{\mathrm{a}}$ at (504) 383-0000 and specifying extension 4444 for the East Baton Rouge Parish Office of Emergency Preparedness. The NWS has direct access to USGS for use in their forecasting models, and broadcasts this forecast information routinely to the news media and on shortwave radio at a frequency of $162.40 \mathrm{MHz}$ (megahertz).

To use the chart for a particular property, determine the approximate elevation of the threatened property and record this in the appropriate box (at the top of the map) along with the "key gaging station." The "key gaging station" is the station that is closest to the threatened property. For example, most people in Denham Springs, Louisiana, probably will use the Amite River near Denham Springs station as their "key gaging station." By the ways described above, routinely find out the latest river stage information. Record this information at each station, especially the "key gaging stevation of the property to immediately know if the property has an impending threat of flooding. One must be cautioned by the fact that the surface of
flowing water is not flat, but has slope, and that the water-surface levation near a threatene

property might not be the same a the river stages at these gaging stations because of this slope.

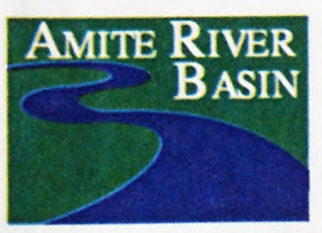

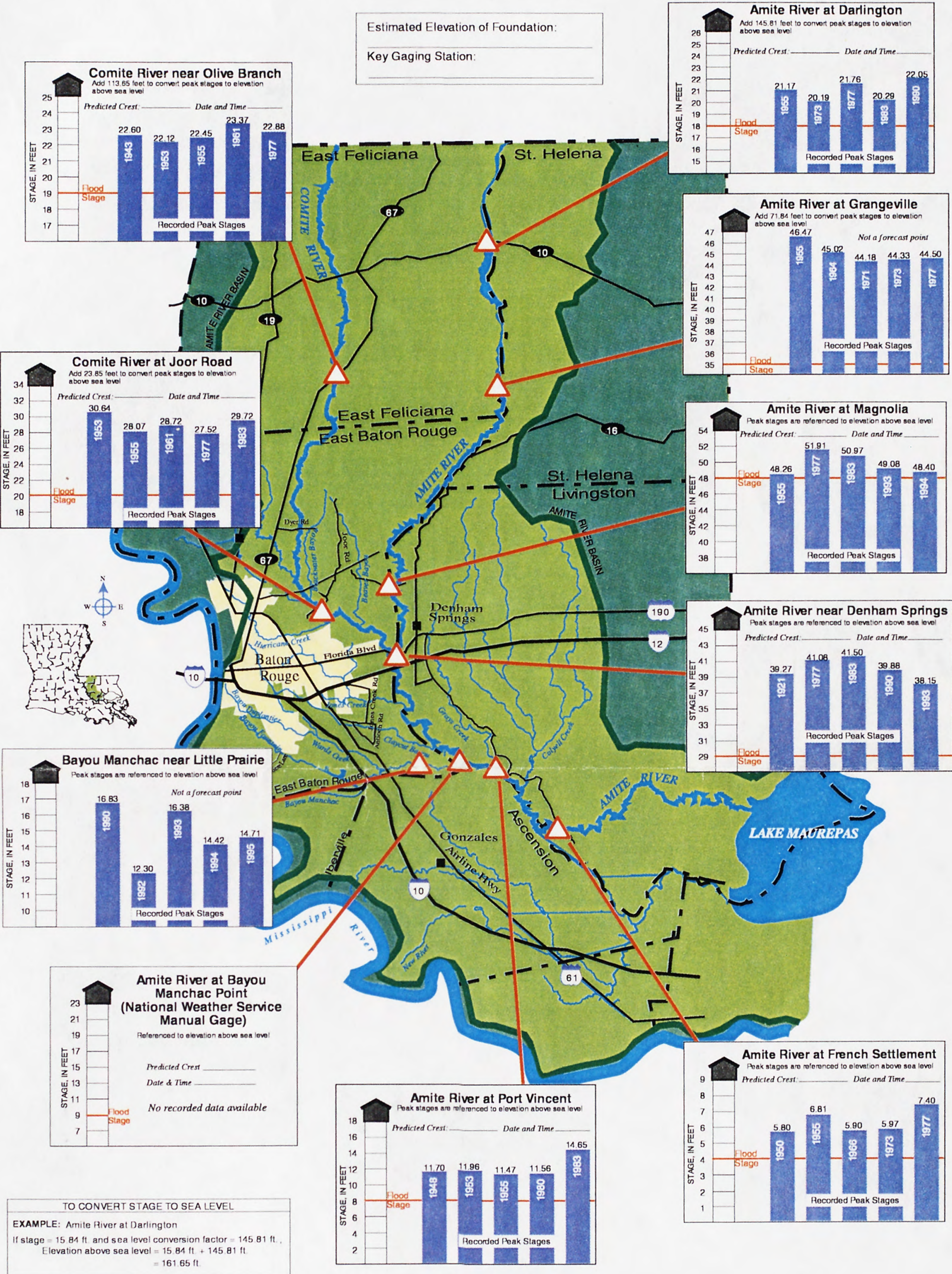

Four of the stations in the upper part of the basin must have their reading adjusted to express those readings as elevation above sea level The adjustment factor for each of these stations is shown in the corresponding box for that station, and can be added he current river stage and also to the historical recorded peak stages to relate this information to See the example in the lower left cons. of the map.
The flood tracking chart was produced as part of a cooperative program between the USGS and the Amite River Basin Drainage and Water Conservation Distric The network of river gaging stations is operated by the USGS, in cooperation with several Federal, State, and local agencies. These agencies include the U.S. Army Corps of Engineers, Louisiana Office of Emergency Preparedness, Louisiana
Department of Transportation and Development, East Baton Rouge Parish, and the Amite River Basin Drainage and Water Conservation District.

Any use of trade, product, or firm names is for descriptive
purposes only and docs not imply cndorsement by the U.S. Geological Survey.

For additional information, writc to:

District Chicf

U.S. Geological Survey

3535 S. Sherwood Forest Blvd., Suite 120 Baton Rouge, LA 70816
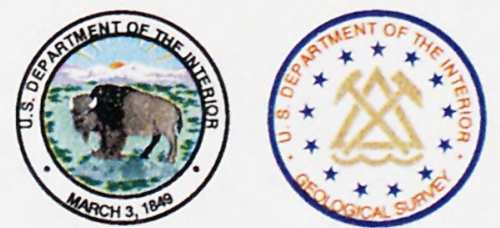

J.S. GEOLOGICAL SURVEY Lonisiana District 